\title{
Sigara Bağımlıı̆̆ıyla Mücadelede Kamu Spotlarının Kullanımı: Sigarayı Bırak Hayatı Bırakma Kamu Spotlarının Göstergebilimsel Çözümlemesi
}

\section{The Use of Public Spots with a Cigarette Depression: The Indicative Solutions of Public Spots Leaving Life from Smoking}

\author{
Nural İmik Tanyıldızı a, Hacı Mehmet Acar ${ }^{\text {b,* }}$ \\ ${ }^{a}$ Doç. Dr., Fırat Üniversitesi, İletişim fakültesi, Halkla İlişkiler ve Tanıtım Bölümü, Elazığ/Türkiye \\ ORCID: 0000-0002-9177-759X. \\ b Öğr. Gör., Mersin Üniversitesi, Sosyal Bilimler MYO, Mersin/Türkiye \\ ORCID: 0000-0001-8426-4051
}

\section{MAKALE BILGİSI}

\section{Makale Geçmiși:}

Başvuru tarihi: 16 Ağustos 2018

Düzeltme tarihi: 05 Eylül 2018

Kabul tarihi: 30 Ekim 2018

\section{Anahtar Kelimeler:}

Sigara

Bağımlılık

Kamu Spotu

\section{ARTICLE INFO}

\section{Article history:}

Received 16 August 2018

Received in revised form 05 September 2018

Accepted 30 October 2018

\section{Keywords:}

Smoking

Addiction

Public Spot

\section{ÖZ}

Sigara bağımlılı̆̆ı çağımızın en önemli sağlık sorunlarından biridir. Sigara bağımlılığını azaltmak için kullanılan en etkili yolardan biri de medyadır. Özellikle televizyon ve radyolarda yer alan sigarayı bırakmaya yönelik kamu spotları, halkı bilgilendirmek ve sigara kullanımını azaltmak için kullanılmaktadır. Araştırmanın amacı sigaraya yönelik oluşturulan kamu spotlarının hedef kitleye mesajları nasıl aktardığını gösteren ve gösterilen ilişkisi içerisinde ortaya koyabilmektir. Araştırmada Sağlık Bakanlığının yapmış olduğu "Sigarayı Bırak Hayatı Bırakma" kamu spotları göstergebilimsel çözümleme yöntemi ile incelenerek, hedef kitleye mesaj aktarımının göstergeler üzerinden ne şekilde yapıldığı ortaya konulmaya çalışılmıştır. Araştırmada sonuç olarak incelenen üç kamu spotunda da hedef kitleyi sigara ve zararlarına karşı uyarıcı, aynı zamanda eğitici mesajların olduğu, sigaraya ve zararlarına karşı farkındalık yaratma noktasında kullanılan görsel göstergelerin düz anlamlarının yanı sıra yan anlamlarıyla da mesajı verebildiği, sigaranın kendisi gösterilmeden tamamen göstergeler üzerinden sigaraya işaret edildiği görülmüştür.

\section{A B S T R AC T}

Smoking addiction is one of the most important health problems of our time. One of the most effective ways to reduce cigarette addiction is mediating. Public spots for smoking cessation, especially on television and radio, are used to inform the public and to reduce smoking. The aim of the research is to show how the public spots directed to the cigarette transmit the message to the target group and show it in the relationship shown. In the research, the public spots of "Stop Smoking", which the Ministry of Health has made, were analyzed by the semiotic analysis method and it was tried to show how the message transmission to the target group was done through the indicators. As a result of the research, it was seen to be the three public spots in the study also warn the target group against smoking and its harmful effects, and also have instructive messages, visual indications used in the point of raising awareness against smoking and harm, as well as giving meaning to their meaning with their semantic meanings.

\section{Giriş}

İnsanlara sağlık davranışlarını kazandırmakta en önemli rolü sağlık iletişimi oynamaktadır. Çünkü iletişim ile insan davranışının temeli olan güdülenme ve tutum değiştirme hızlanmaktadır. Kısacası iletişim ile birey olumlu bir sağlık davranışını kazanmak için ikna edilebilmektedir (Tabak, 2006:66). Sağlık iletişimi, insanlara sağlıkla ilgili konularda yardım etmekte ve daha iyi hayat şartları oluşturmak için onları bilgilendirmekte ve ikna etmektedir (Duffy ve Thorson, 2009: 93). Sağlık iletişimi toplum içinde bireylerin sağlığından ve yaşam kalitelerinin iyileştirilmesinden, ulusal ve evrensel sağlık programlarının hazırlanmasına, sağlık programlarının düzenlenmesine kadar oldukça kapsamlı ilgi alanlarını içermektedir (Becerikli, 2012: 164).

Günümüzde insanlar sağlığı geliştirmeye ve korumaya yönelik kampanyalar sayesinde sağlıkla ilgili konularda daha

\footnotetext{
* Sorumlu yazar/Corresponding author.

e-posta:nimik@firat.edu.tr
} 
fazla bilgi sahibi olmakta ve sağlıklı yaşamak için neler yapılması gerektiğini öğrenebilmektedir (Okay, 2014: 212). Sağlık kampanyaları, direkt ya da dolaylı yollarla toplumda davranış değiş̧ikliği için çalışmaktadır. Birçok kampanyanın hedefi, bireysel düzeyde karar verme sürecini etkilemektir (Wakefield vd., 2010' dan aktaran: Avcı ve Avşar, 2014: 185). Bu kampanyalar dahilinde bazen kamu spotlarından da yararlanılmaktadır. Kamu spotları kâr amacı gütmeyen kuruluşlar için eğitim, sağlık, çevre, insan hakları, kadın hakları gibi önemli konularda, düşünmeye sevk eden, farkındalık oluşturan, bazı düşünce ve davranışların değiştirilebilir olduğunu hissettirmede önemli roller oynamaktadır. Türkiye'de kamu spotu kavramı yerine zaman zaman "kamu yararı spotu", "sosyal reklam" "kamu eğitim kampanyası", "sosyal pazarlama” gibi kavramlar da kullanılmıştır (Aytekin, 2016: 250-251).

Yapılan literatür çalışmasında sigara bağımlılı̆̆ı ile mücadeleye yönelik birçok çalışmaya rastlanmıştır. Konuyla ilgili Türkiye'de Şeker ve Tiryaki'nin yazdığı sigarayla ilgili kamu spotlarında moral panik etkisini ele alan bir makaleye ulaşılmıştır. Makalede hem spotlarda yer alan bireylere ait söylemin hem de diş ses ve göstergelerde yer alan söylemin moral panik için kullanıldığı ve bu şekilde gerçekçiliği artırılarak, izleyenlerin kendisine ait bir ögeyi spotlarda yakalamasının kolaylaştırıldığı ortaya konulmuştur (Şeker ve Tiryaki, 2013:240). Yurt dışında ise kitle iletişim araçları ve sigaraya yönelik yapılan çalışmaların çoğunun gençler üzerinde odaklandığ Brown ve Witherspoon, 2002; Primack vd, 2006; Dietz vd, 2013; Chauhan ve Sharma, 2017; Park vd, 2017) . Bu çalışma da ise sigara bağımlılığı ile mücadelede "Sigarayı Bırak Hayatı Bırakma" kamu spotlarının kullanımı, kamu spotlarının göstergebilimsel çözülemesi ile açıklanmak istenmiştir. Sigarayı bıraktırmaya ve sigara konusunda toplumu bilinçlendirmeye yönelik hazırlanmış olan kamu spotlarında hedef kitleye mesajların göstergeler yoluyla nasıl verildiği ortaya konulmaya çalışılmıştır.

\section{Sağlık İletişimi}

Sağlıkla ilgili konularda iletişim araçları topluma olumlu ya da olumsuz etkide bulunabilmektedir. Örneğin popüler kültürün de etkisiyle filmlerde sigara kullanımının yaygın olması sigara kullanımını artırmakta (McCool vd., 2001: 1577) ama aynı zamanda yine kitle iletişim araçlarının etkisi ile sigaranın zararları topluma aktarılmaktadır.

Sağlık iletişimi 70'li yıllardan itibaren öncelikle Kuzey Amerika iletişim bilimlerinde gelişmeye ve yaygınlaşmaya başlamıştır. Ülkemizde ise konu son yıllarda gelişme göstermiştir. Sağlık iletişimi sağlık konusu ile ilgili kişilerin, grupların, ilgili hedef gruplarına yönelik gerçekleştirmiş olduğu iletişim şekline denilmektedir (Okay, 2014: 10-11). Sağlık iletişimi bir sağlık sorununa veya çözümüne ilgiyi artırabilmekte, sağlık hizmetleri için talep olduğunu ortaya koyabilmekte, hedef kitlenin sağlıkla ilgili olumsuz davranışlarını değiştirmede etkili olabilmekte ya da bu konuda yapılan enformasyonu tamamlamakta veya artırmaktadır (Çınarlı, 2008: 48). Sağlık iletişiminin günümüzdeki amaçlarını sağlı̆ıı geliştirilmesi çabalarına uygun olarak bilgilendirme, enformasyon alışverişi yapma, hedef kitleleri motive etme, tutumları, davranışları değiştirme, anlamları ya da enformasyonu paylaşma ve bireyleri ya da toplulukları etkileme, politikalar oluşturma ve ayrıca da sosyal değişimi destekleme ve sürdürme olarak sıralamak mümkündür (Schiavo, 2007: 7; Çınarlı, 2016: 211 212).

Sağlık iletişiminin genişleyen kapsamı; hiç şüphesiz ki sağlığın anlamlandırılmasını ve dolayısıyla da hastalık, rahatsızlık kavramlarının tanımlanmasını daha karmaşık hale getirmiştir. Sağlık tıb bileştirilmiş ve bireyselleştirilmiştir. Böylece dikkatler medyanın da etkisi ile hastalığa neden olan sosyal, ekonomik ve siyasi etmenlerden uzağa çekilmektedir. Örneğin tütün ve tütün mamullerinin tüketilmesine yönelik sağlı iletişimi kampanyalarında sigaradan kaynaklanan hastalıklara yer verilerek bireyden bu zararlı alışkanlığını bırakması istenirken, sigara üreticilerinin sorumlulukları üzerinde genellikle durulmamaktadır (Çınarlı, 2016: 213). Bunların yanında, hastalığa neden olan sosyal, ekonomik vs. etmenler üzerinde de durulmasında fayda vardır.

Sağlık alanında yapılan iletişim çalışmaları çok farklı şekillerde gerçekleşmektedir. Hekim ile hasta arasındaki yüz yüze iletişimden broşüre, televizyondan internete kadar uzamaktadır. Fakat sağlık alanında çok sayıda insana ulaşmanın en etkili yolu kitle iletişim araçlarını kullanmaktır (Okay, 2014: 47-65). Toplumu özellikle de gençleri sağlık konusunda bilgilendirmek için iletişim teknolojilerinden, dijital medyadan yararlanılabilir (Park vd., 2017: 203). Kitle iletişim araçlarının öncelikli görevi toplumu bilgilendirmektedir. Bilgilendirmenin içerisine halkı eğitmek de girmektedir. Bu araçların bir diğer işlevi ise kamuoyu oluşturmaktır (Tengilimoğlu, 2001: 103). Sağlık iletişiminde ise kitle iletişiminin rolünü; kamunun farkındalığını artırmak, bir fikir ortamı yaratmak, tutumları biraz olsun değiştirmek ve davranış değişikliği yaratmak olarak siralamak mümkündür (Naidoo ve Wills'den aktaran: Çınarl1, 2008: 95-96). Medyadan sağlık bilgisi öğrenilmesi iki şekilde olmaktadır. Bunların ilki aktif olarak kişilerin sağlık bilgisi araştırması şeklindeyken, ikincisi ise pasif olarak sağlık kampanyaları şeklinde gerçekleşmektedir (Avcı ve Avşar, 2014: 183).

\section{Sağlık İletişimi Çalışmalarında Kamu Spotlarının Kullanımı}

Kitle iletişim araçlarından televizyon, sağlik konusunda bazen olumsuz sağlık mesajlarına yer veresede en önemli enformasyon kaynaklarından biridir. Televizyonda haber, belgesel, darama, reklam gibi birçok program sağlıkla ilgili konulara yer vermektedir (Çınarlı, 2008: 100-101). Bu programlardan biri de kamu spotlarıdır. Kamu spotları kamu kurum ve kuruluşları ile dernek ve vakıf gibi sivil toplum kuruluşlarınca hazırlanan veya hazırlatılan ve Üst Kurul tarafından yayınlanmasında kamu yararı olduğuna karar verilen bilgilendirici ve eğitici nitelikteki film ve sesler ile alt bantları ifade etmektedir (RTÜK, Kamu Spotları Yönergesi, Madde 3 /b, 2012).

Sosyal öğrenme kuramı son yıllarda sağlık iletişimi çalışmalarında yoğun bir şekilde kullanılmaktadır. Bu öğrenmenin temel düşüncesi bireylerin belli bir davranışta bulunan model bireyleri gözleyerek öğrenmesidir. Model günlük hayatta olabildiği gibi kitle iletişim araçları tarafından da tanımlanıp sunulabilmektedir. Burada pozitif ve negatif modeller vardır. Pozitif modeller izleyici için çekici olmalıdır (Tabak, 2006: 121). Bu noktada sağlık 
alanındaki kamu spotları da izleyicilere sağlıkla ilgili belli konulardaki modelleri tanımlayarak sunmaktadır.

Bir tutum yaratma, değiştirme veya pekiştirmeye yönelik kamu spotlarının hazırlanma aşamasında dikkat edilmesi gereken en önemli noktalar: birden fazla iddiadan çok tek bir iddianın verilmesi, verilen mesajın akılda kalıcılığını pekiştirecek ve beklenen iknayı sağlayacak orijinal, yenilikçi ve beklenmedik bir fikre sahip olması, izleyici ile arasında bir bağ kurması ve güçlü bir prodüksiyon kalitesine sahip olması şeklinde sıralanabilir (B1cal ve Y1lmaz, 2012: 51). Ayrıca son yıllarda sağlık enformasyonunu içeren kampanyalarda bireyleri sağlığa zararlı davranışlarından vazgeçirmek ve davranışı değiştirmeye yönelik motivasyon oluşturmak için hazırlanan materyallerde korku öğesinin kullanımı yaygın bir şekildedir. Bunun nedeni ise bir fikrin benimsetilmesi ya da değiştirilmesini sağlayabilmektir (Çobaner, 2013: 212). Fakat korku motifleri kullanılırken, yaratılacak endişeyi azaltacak mekanizmaların da eşlik etmesi sağlanmalıdır (Tabak, 2006: 120). Bu nedenle sağlıkla ilgili konularda toplumu etkilemek, bilgilendirmek vs. gibi görevleri olan kamu spotlarındaki mesajların hedef kitleye nasıl aktarıldığı, kullanılan motifler ve gösterengösterilen ilişkisi kamu spotunun amacına ulaşmasında önem kazanmaktadır.

\section{Sigarayı Bırak Hayatı Bırakma Kamu Spotunun Göstergebilimsel Çözümlemesi}

\subsection{Araştırmanın Amacı ve Önemi}

Araştırmanın amacı çağımızın en önemli sağlık sorunlarından biri olan sigara bağımlılığının azaltılması ve kamunun bilgilendirilmesi için sigaraya yönelik oluşturulan kamu spotlarının hedef kitleye mesajları nasıl aktardığını gösteren ve gösterilen ilişkisi içerisinde ortaya koyabilmektir. Araştırma yapılan tespitler neticesinde sigaraya yönelik olarak hazırlanan medya mesajlarının özellikle kamu spotlarının verdiği mesajlarda nelere dikkat edilmesi gerektiğini ortaya koyması ve gelecekte yapılacak çalışmalarda bunların dikkate alınmasını sağlaması açısından önemlidir.

\subsection{Araştırmanın Hipotezi}

Araştırmanın temel hipotezi Sağlık Bakanlığı'nın yapmış olduğu Sigarayı "Bırak Hayatı Birakama" kampanyası kapsamında oluşturulan kamu spotlarında negatif ve pozitif mesajların birlikte verildiğidir. Yine, önemli ve etkili görsel iletişim çalışmalarından biri olan kamu spotlarının, bağımlılıkla mücadele kapsamında insanlar üzerinde olumlu etkileri olduğu ve sağlığa zararlı davranışlarından vazgeçirebildiği veya davranışı değiştirmeye yönelik motivasyon oluşturduğu varsayılmaktadır. Ayrıca, sigaraya ve zararlarına karşı farkındalık yaratma noktasında kullanılan görsel göstergelerin düzanlamlarının yanı sıra yananlamlarıyla da mesajı verebildiği ve çözümleme yapılan üç filmde de sigaranın kendisi gösterilmeden tamamen göstergeler üzerinden sigaraya işaret edildiği yan hipotezinden hareket edilmiştir.

\subsection{Araştırmanın Örneklemi ve Yöntemi}

Araştırmada yer alan T.C. Sağlık Bakanlı̆̆ı tarafından hazırlanan "Sigarayı Birak Hayatı Bırakma" kamu spotlarında yer alan göstergelerin çözümlenmesi, düzanlam ve yananlamlarında ortaya çıkan mesajları okumak için göstergebilimsel çözümleme yöntemi kullanılmıştır. Göstergebilim insanların, kendilerini ilgilendiren her konuya göstergeler aracılığıyla yaklaştığını varsayar ve bu olguyu inceler (Erkman-Akerson, 2005: 14). Göstergebilim film, tiyatro, mimarlık, iletişim gibi birçok alana uygulanmış ve ilginç sonuçlara ulaşılmıştır. Bazı göstergebilimcilere göre her şey bu yöntemle çözümlenebilmektedir. Göstergebilimin temel özelliği; dilbilimi bir model olarak alıp, dilbilimsel kavramları yalnızca dille değil, diğer görgünlere uygulamaktır (Berger, 1982: 13-14). Göstergebilimin temel ilgi alanının merkezinde gösterge yer alır. Gösterge, bir gösteren ile bir gösterilenden kuruludur (Barthes, 1993: 40).

Birçok kaynağa göre göstergebilimin temelleri 20. yy’ın başlarında Amerikalı filozof C. Sanders Peirce ile İsviçreli dilbilimci Ferdinand de Saussure tarafından neredeyse aynı zamanda birbirinden habersiz bir şekilde atılmıştır. Peirce (1982: 339), göstergeyi bir şeyin yerini tutan, o şeyi üreten ya da niteleyen bir düşünce olarak ifade etmiştir. Ferdinand de Saussure ise öncelikle dil olgusunun ne olduğunu tanımlamakla işe başlamış ve doğal dil dizgelerini inceleyen dilbilimi, daha geniş bir bilim dalı olan göstergebilimin içinde değerlendirmiştir.

Film, afiş, billboard vb. gibi görsel göstergebilim alanında yapılan çalışmalarda Roland Barthes'ın yaklaşımlarından da söz etmek gerekir. Barthes, anlamlandırmanın 'düzanlam ve yananlam' olarak iki boyutundan bahsederek Saussure'un göstergebilim tanımını geliştirmiştir. Düzanlam, gösterenin kendisi iken, yananlam ise gösterileni ifade etmektedir. Barthes'ın görüntülerdeki anlamlandırma kuramında anahtar düşünce, anlamın düzanlam, yananlam boyutunda nasıl yayıldığıyla ilgilidir. Birinci düzlemdeki anlam boyutu olan düzanlamda, bir göstergede "kim" ya da "ne" gösterildiği belirlenirken, ikinci anlam düzlemi olarak görünenin altında görünmeyen anlamı ifade eden yananlamda ise hangi değerler, kanaatler ve fikirlerin bulunduğu tespit edilmektedir (Parsa, 2008: 123).

Göstergebilim bilgisi, bir tasarımcının çalışmalarına çok sayıda katman üzerinden kitleye erişebilecek göndermeler yerleştirmesini sağlar (Ambrose ve Harris, 2012: 66). Görsel iletişim çalışmalarında göstergebilimsel çözümleme yapılırken ilk olarak, tasarım unsurlarının nasıl düzenlendiği dizisel boyutta incelenerek ele alınmalıdır. $\mathrm{Bu}$ araştırmada yer alan tasarım unsurlarının hangi kavramları karşıladığı ve imgesel boyutta neyi karşıladığı tespit edilmeye çalışılmıştır. Mesajın, düzanlam (denotation) ve yananlam (connotation) olarak ifade ettikleri belirlenmiş ve göstergelerin birbirileriyle olan ilişkilerinin oluşturdukları anlamlar ortaya çıkarılmıştır. Araştırmanın örneklemi olan kamu spotlarında yer alan göstergelerin çözümlenmesinde, gösteren ve gösterilen bağlamında semantik ve hermeneutik analiz yöntemlerinden de yer yer faydalanılmıştır.

\subsection{Verilerin Çözümlemesi}

Günümüz dünyasında birçok ülkede kapalı alanlarda sigara içilmesi yasaklanmış durumdadır. Türkiye'de de 4207 sayılı "Tütün Ürünlerinin Zararlarının Önlenmesi ve Kontrolü 
Hakkında Kanun" ile 2008 yılında yapılan düzenlemelerle kamuya açık tüm kapalı alanlarda, 2009 yılında ise kapsam genişletilerek özel hukuk kişilerine ait olan lokanta, kahvehane, kafeterya vb. işletmelerde tütün ve tütün ürünlerinin tüketilmesi yasaklanmıștır. Bu yasak ile sigara kullanmayan kişilerin başkalarının kullandığı sigara dumanından zarar görmesinin engellenmesi hedeflenmiştir.

Bununla birlikte T.C. Sağlık Bakanlığı bu konu üzerine halkı bilinçlendirmeye yönelik bazı çalışmalar yapmaktadır. T.C. Sağlık Bakanlığı Sağlığın Geliştirilmesi Genel Müdürlüğü tarafından tütün ve tütün ürünlerinin tüketilmemesi ve bu konuda toplumun bilinçlendirilmesi kapsamında çeşitli kampanyalar da düzenlemektedir. Bunların başında da kamu spotları gelmektedir. 2017 yılında "Sigarayı Bırak Hayatı Bırakma Kamu Spotu” (4207 Sayılı Kanun Kapsamında) başlığı ile 3 adet film hazırlanmıştır ve televizyonda gösterilmektedir. Araştırma kapsamında bu üç kamu spotunun çözümlemesi yapılmıştır.

Hazırlanan filmlerin birbirinin devamı niteliğinde olduğu söylenebilir. İlk iki fillm, sigara içenlere yönelik hazırlanmış ve sigara içmeye devam etmeleri halinde başlarına gelebilecek olası sağlık sorunları örnek gösterilerek daha çok uyarıcı nitelikteki görüntü ve mesajlardan oluşmaktadır. Üçüncü film ise ilk iki filmin toplum üzerindeki etkilerinin olumlu sonuçlar verdiğini gösterir nitelikte olduğunu göstermekte ve sigara içmeye devam eden kişileri de özendirici nitelikte görüntü ve mesajlara yer vermektedir. İlk iki filmde sigara içerek sigaradan zarar görenler ile sigara içmeye devam edenlerin hikayesi işlenirken üçüncü filmde ise sigara içmeye devam edenlerle sigara içmeyi bırakmayı başarmış kişilerin hikayesi aktarılmıştır.

Üç filmin başlama sahnesinde de herhangi bir jenerik vb. görüntü yer almazken filmler, doğrudan hikayenin kendisi ile başlar. Bununla birlikte üç filmin kurgusu da benzer şekilde oluşturulmuştur. Filmlerin son sahnelerinde ise "Sigarayı Bırak Hayatı Bırakma" dilsel iletisi dış ses ile birlikte gösterilirken hemen arkasından sigarayı bıraktırmaya yönelik bilgi ve dokümanların bulunduğu "bırakabilirsin.org" internet sitesinin adresi verilmektedir. Aynı sahnede ekranın sol alt kısmında sosyal medya simgeleri, sağ alt kısımda ise Tütün ve Alkol Piyasaları Denetleme Kurumu ile T.C. Sağlık Bakanlığı logoları yer almaktadır. Üç fillm de Yeşilay logosunun görünmesiyle sona ermektedir.

"Sigarayı Bırak Hayatı Bırakma" sloganında kullanılan renkler incelendiğinde, "Sigarayı bırak" kısmında turuncuya yakın kirli ve soluk bir sarının kullanılmasını hastalığın, "hayatı bırakma" kısmında saflığın ve temizliğin sembolü olan beyazın kullanılmasını ise sağlığın göstergesi şeklinde değerlendirmek mümkündür.

Araştırmanın bu bölümünde T.C. Sağlık Bakanlığı Sağlığın Geliştirilmesi Genel Müdürlüğü tarafından tütün ve tütün ürünlerinin tüketilmemesi ve bu konuda toplumun bilinçlendirilmesi için 2017 yılında "Sigarayı Bırak Hayatı Bırakma Kamu Spotu” (4207 Sayılı Kanun Kapsamında) başlığı ile hazırlanan kamu spotlarının analizleri yapılmıştır. $\mathrm{Bu}$ kapsamda hazırlanan üç farklı filmin sahneleri ayrı ayrı değerlendirilmiştir. Sahnelerde yer alan göstergelerin gösteren ve gösterilen bağlamında gösterge çözümlemeleri yapılarak düzanlam ve yananlamlarındaki mesajlar açı̆̆a çıkarılmaya çalışılmıştır.
Resim 1. Sahneler
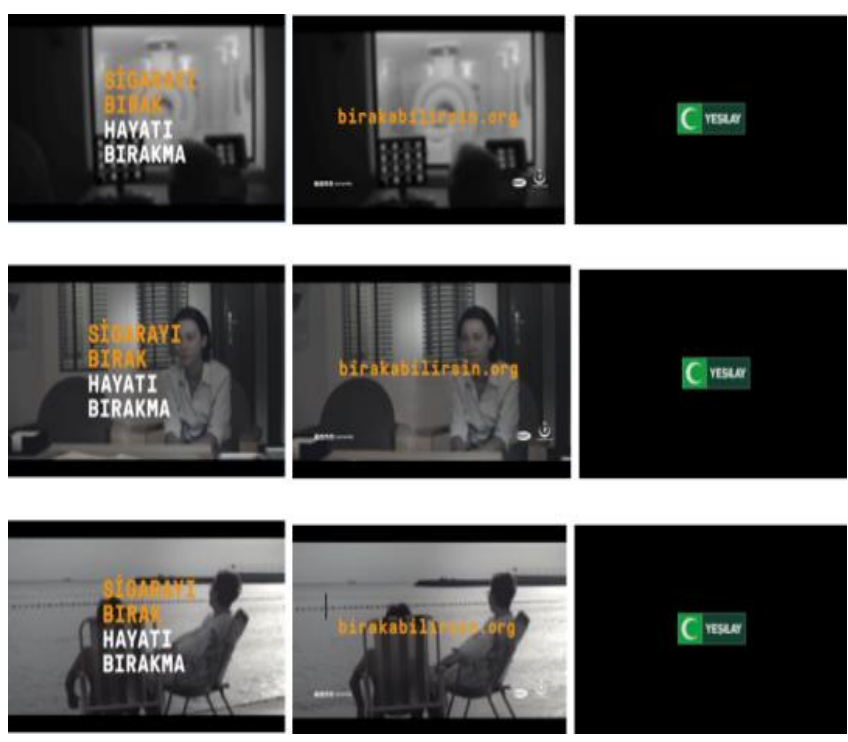

Birinci Kamu Spotunun Çözümlemesi:

Sekiz sahneden oluşan ilk filmde sigaranın zararları, oyuncuların benzer yönlerine göndermeler yapılarak anlatılmıştır. Filmin sahneleri sigara içmeye devam eden ve sigaradan zarar gören hastalar olarak kurgulanmıştır ve kullanılan sahneler birbirini tamamlar niteliktedir. $\mathrm{Bu}$ nedenle gösterge çözümlemesi yapılırken anlam bakımından birbirileriyle ilişkili sahneler birlikte değerlendirilmiştir.

Resim 2. Sahne-1

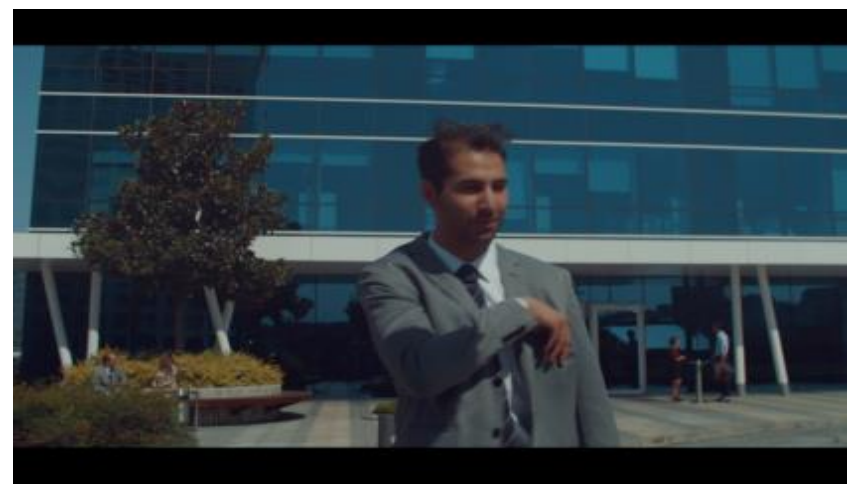

Resim 3. Sahne-2

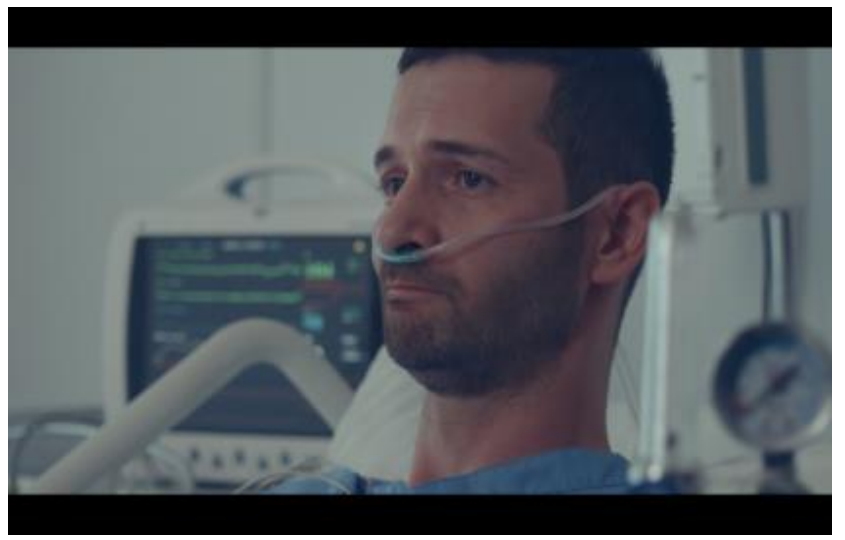


Tablo 1. Sahne-1 ve Sahne-2 Gösterge Çözümlemesi

\begin{tabular}{|c|c|c|}
\hline \multicolumn{2}{|c|}{ Gösterge Gösteren } & \multirow{2}{*}{$\begin{array}{l}\text { Gösterilen } \\
\text { Çalışan insan, eğitimli } \\
\text { insan, sosyal statü }\end{array}$} \\
\hline İnsan & $\begin{array}{l}\text { Takım elbiseli, kravatlı } \\
\text { erkek oyuncu }\end{array}$ & \\
\hline İnsan & $\begin{array}{l}\text { Erkek oyuncunun elinin } \\
\text { cebinde olmas1 }\end{array}$ & Birazdan sigara içileceği \\
\hline Nesne & Camlı bina & İş merkezi, holding vb. \\
\hline İnsan & $\begin{array}{l}\text { Kirli sakallı, hüzünlü erkek } \\
\text { oyuncu }\end{array}$ & Hasta ve üzgün insan \\
\hline Nesne & $\begin{array}{l}\text { Erkek oyuncunun yüzünde } \\
\text { hortum olması }\end{array}$ & Tedavi gören hasta \\
\hline Nesne & Oksijen tüpü göstergesi & Solunum problemi \\
\hline Nesne & Dijital ekran & $\begin{array}{l}\text { Hastane odası, hastalığın } \\
\text { ciddiyeti }\end{array}$ \\
\hline Renk & Beyaz & Hastane odas1 \\
\hline
\end{tabular}

Film, cam kaplamalı modern bir binadan çıkan takım elbiseli, kravatlı ve orta yaşlarda olduğu düşünülen birinin görüntüsü ile başlamaktadır. Bu kişi "Sigarasız birkaç saat bile duramiyorum" şeklinde bir cümle kurduktan sonra elini cebine doğru götürmektedir. Göstergelerin anlattığ iletide verilmek istenen bu kişinin aslında eğitimli, belirli bir statüye sahip ve arkasında iş merkezi izlenimi veren binada çalışan bir birey olduğudur. Ancak bu kişi aynı zamanda sigara içmektedir. İşlerinin çok yoğun olmasına rağmen dışarı çıkar çıkmaz yaptığı ilk işin sigara içmek olduğu görülmektedir. Elini cebine atması birazdan cebinden çıkaracağı sigarayı içeceğinin göstergesidir.

Hemen arakasindan gelen ikinci sahnede ise hastane odasında burnuna takılı hortumla görünen bir hasta yatmaktadır. Ön tarafta görünen oksijen tüpü göstergesi ve arka plandaki dijital ekran bu kişinin solunuma bağlı bir hastalık yaşadığını ve bu nedenle tedavi gördüğünü aktarmaktadır. Kirli sakalıyla, yorgun ve üzgün görüntüsünün yanında aynı zamanda pişman olduğunu gösteren ağlamaklı bir ifade sergileyen bu hasta, "Makinesiz tek nefes bile alamıyorum" diyerek kendi durumu hakkında kısaca bilgi vermektedir.

İki sahnenin birlikte verdiği mesaja bakıldığında her iki kişinin de yaşlarının birbirine yakın olması dikkat çekmektedir. Hastanede yatan kişinin geçmişte sigara içmesi nedeniyle hastalandığı, hastalığından dolayı solunum cihazına bağlı olduğu ve bu nedenle de pişman olduğu gösterilmiştir. $\mathrm{Bu}$ iki sahne birlikte incelendiğinde, şu an sağlıklı görünen, sigarasız birkaç saat bile duramadığını söyleyen bireye, daha önce sigara içen ve hastalanan birilerinin olduğu, bu kişilerin solunum cihazı olmadan yaşayamadığı ve sigara içmeye devam ederse kendisinin de böyle hasta olabileceği anlatılmaya çalışılmaktadır. Bu iki sahnede zıtlıklardan yararlanılmıştır. "Sigarasız birkaç saat bile duramiyorum" ifadesinde bir yoksunluktan bahsedilirken bunun karşıtı olarak "Makinesiz tek nefes bile alamıyorum" ifadesinde hayatta kalmak için bir gereklilikten bahsedilmektedir. İlk ifadede bir tercih söz konusu iken ikinci ifadede zorunluluk ve mecburiyetten söz etmek mümkündür.
Resim 4. Sahne-3

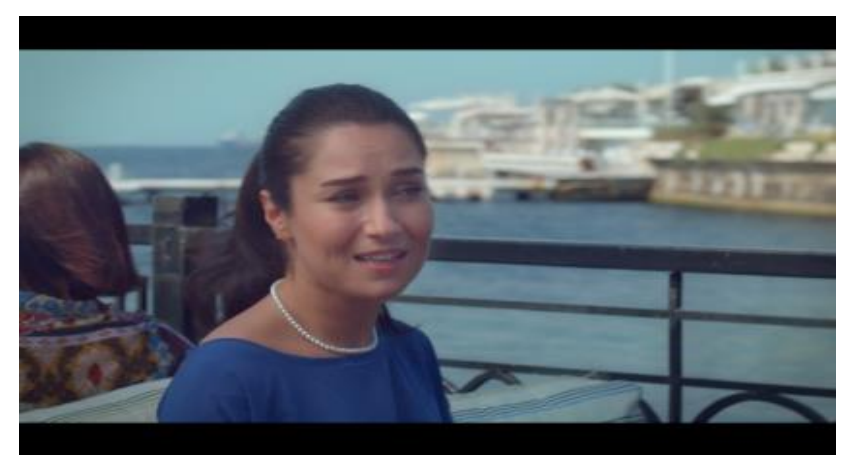

Resim 5. Sahne-4

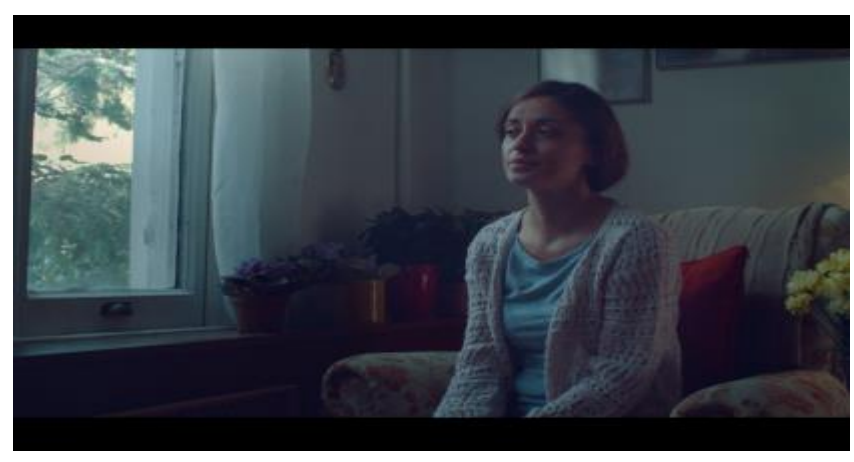

Tablo 2. Sahne-3 ve Sahne-4 Gösterge Çözümlemesi

\begin{tabular}{lll}
\hline \multicolumn{2}{l}{ Gösterge Gösteren } & Gösterilen \\
\hline İnsan & Kadın oyuncu & Genç ve modern kadın \\
\hline İnsan & $\begin{array}{l}\text { Kadın oyuncunun elini } \\
\text { çantasına atması }\end{array}$ & $\begin{array}{l}\text { Birazdan sigara } \\
\text { içileceği }\end{array}$ \\
\hline İnsan & $\begin{array}{l}\text { Arka planda yer alan kadın } \\
\text { oyuncu }\end{array}$ & $\begin{array}{l}\text { Kafe, çay bahçesi vb. } \\
\text { mekan }\end{array}$ \\
\hline Doğa & Mavi gökyüzü, durgun deniz & Açı ve temiz hava \\
\hline İnsan & Kadın oyuncu & Hasta ve üzgün insan \\
\hline Mekan & Pencere ve duvar & İç mekan \\
\hline Mekan & Koltuk & Ev ortamı \\
\hline
\end{tabular}

Üçüncü sahne deniz kenarında çay bahçesi veya kafeterya benzeri bir mekânda oturan kadın görüntüsüyle başlamaktadır. "Ben sadece arkadaşlarımla dışarı çıktığım zaman içiyorum" diyerek çantasını karıştıran kadın, sigarasını aramaktadır. Elini çantasına götürmesi sigara içeceğinin göstergesi olmuştur.

Buna karşın sonraki sahnede görünen kadın, hasta, yorgun, bitkin görüntüsü ve k1sık sesiyle evinin penceresinden özlemle dışarı bakarak "Haftalardır dışarı çıkamıyorum" diyerek içinde bulunduğu durumu dile getirmektedir. Kadının kıyafetlerinden ve bulunduğu mekândan evde olduğu anlaşılmaktadır. Pencerenin önünde oturup dışarı bakması ve perdenin açık olması dışarıya çıkmaya olan özlemini göstermektedir.

Bu iki sahnede de karakterlerin yaş, cinsiyet, eğitim düzeyi, statü gibi benzer yanlarının olduğunu söylemek mümkündür. Geçmişte her ikisi de sigara içmiştir. Biri hala sigara içmeye devam etmekte ve bu bağımlılık durumunu "sadece dişarı çıktığımda" şeklinde ifade etmektedir. Bu söylem onun yaptığı yanlışın farkında olduğunu ve suçluluk duygusunu hafifletmeye çalıştığı izlenimini yaratmaktadır. Diğer karakter ise sigara içtiği için hastalanarak evinden dişarıya çıkamayacak hale geldiğini söyleyerek, bir anlamda sigara içenleri uyarmaktadır. 
Buradaki sloganlarda da zitlıklardan yararlanılmaktadır. "Ben sadece arkadaşlarımla dışarı çıktığım zaman içiyorum" diyen kadının mutlu ve sağlıklı görüntüsünün karşısında "Haftalardır dışarı çıkamıyorum" diyen hasta ve bitkin kadının görüntüsü vardır. Sadece dışarı çıktığınızda içiyor olsanız bile bu bağımlılık sizin bir gün dışarıya çıkmanıza engel olacak kadar hasta olmanıza neden olacaktır mesajı verilmeye çalışılmaktadır.

Resim 6. Sahne-5

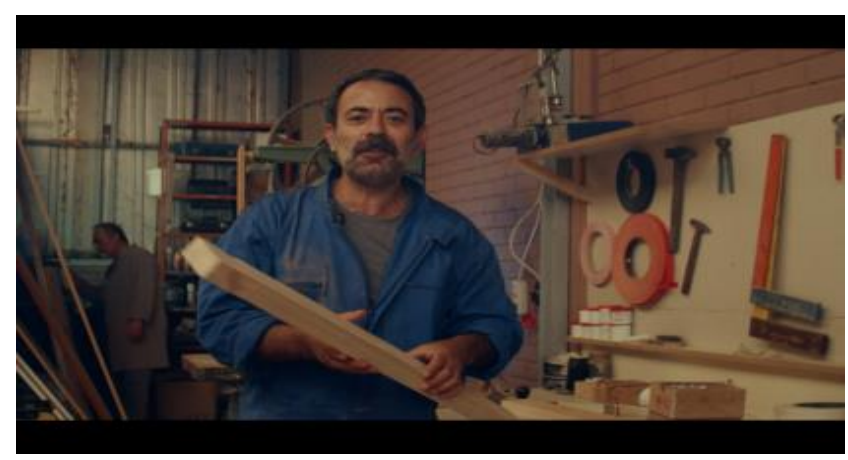

Resim 7. Sahne-6

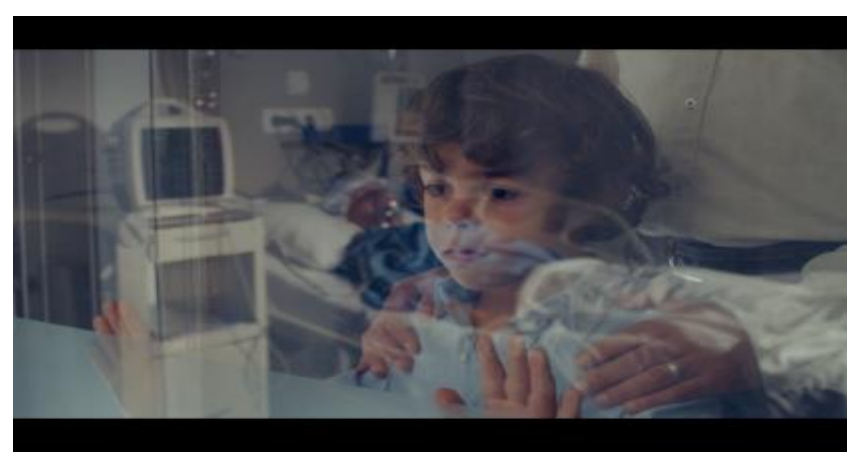

Tablo 3. Sahne-5 ve Sahne-6 Gösterge Çözümlemesi

\begin{tabular}{lll}
\hline Gösterge Gösteren & Gösterilen \\
\hline İnsan & Erkek oyuncu & Marangoz \\
\hline Nesne & $\begin{array}{l}\text { Oyuncunun elindeki tahta } \\
\text { parças1 }\end{array}$ & Marangozhane, atölye \\
\hline Nesne & Arka planda yer alan alet edevat & Marangozhane, atölye \\
\hline İnsan & Çocuk & Evlat \\
\hline İnan & Eller & Baba \\
\hline İnsan & Yatakta yatan hasta & Anne \\
\hline Nesne & Yüzük & Evlilik, aile \\
\hline Nesne & Alet, elektronik cihazlar & $\begin{array}{l}\text { Hastane, yoğun } \\
\text { bakım }\end{array}$ \\
\hline Nesne & Cam & Yoğun bakım \\
\hline
\end{tabular}

Filmin beşinci sahnesinde görünen kişinin üniforması ve kullandığı aletlerden bu kişinin bir marangoz olduğu anlaşılmaktadır. "Yok! hiç bırakmak istemiyorum" diyerek sigara içtiğini ve bırakmak istemediğini söylemektedir.

Altıncı sahnede ise ellerini cama yaslamış bir çocuğun yakın plan çekimi görülmektedir. "Annem beni biraksın istemiyorum" diyen çocuğun omuzlarında görünen ellerin babasına ait olduğu anlaşılmaktadır. Ellerini yasladığı camın diğer tarafinda yatan kişinin de çocuğun annesi olduğu, çocuğun oraya bakarak konuşmasından anlaşılmaktadır. Çocuğun omuzundaki elin parmağında bulunan yüzük o kişi ile yatakta yatanın eş olduğu ve çocuğun da onların çocuğu olduğu şeklinde yorumlanabilmektedir. Cihazlar ise mekanın bir yoğun bakım odası olduğu izlenimini yaratmaktadır.

Bu iki sahnede diğerlerinden farklı olarak kelimelerin başka anlamlarda kullanılarak mesaj verildiği söylenebilir. Her iki replikte "bırakmak" fïili farklı anlamlarda kullanılmıştır. Marangoz sigarayı birakmaktan bahsederken, çocuk annesinin kendisini terk etmesinden bahsetmektedir. Yani iki sahnenin birlikte "Sigara içerseniz hastalanabilir ve çocuğunuzu terk edebilirsiniz. Sevdiklerinizin yanında kalmak istiyorsanız sigarayı terk edin" şeklinde mesaj vermektedir.

Resim 8. Sahne-7

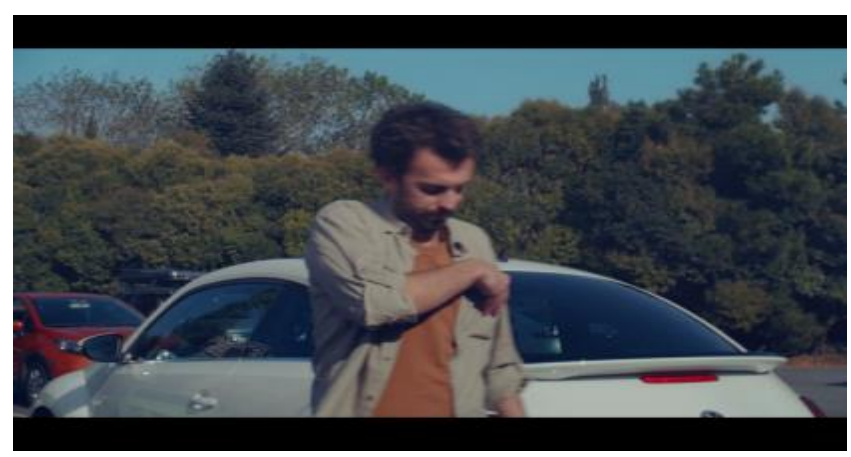

Resim 9. Sahne-8

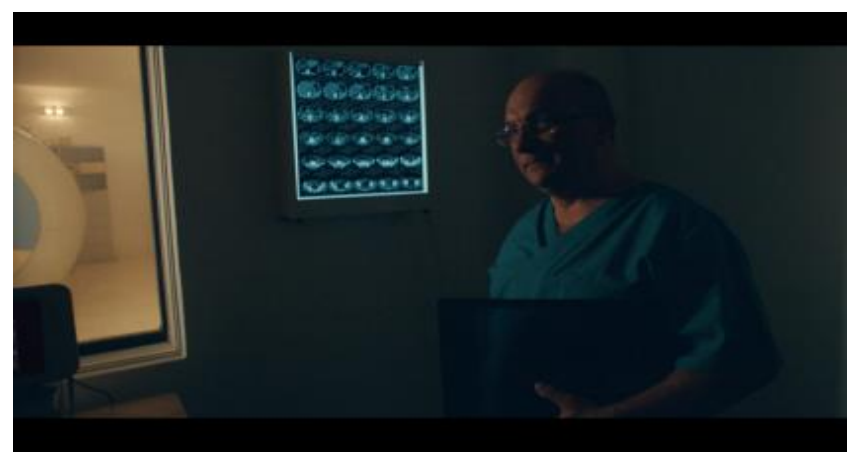

Tablo 4. Sahne-7 ve Sahne-8 Gösterge Çözümlemesi

\begin{tabular}{lll}
\hline Gösterge & Gösteren & Gösterilen \\
\hline İnsan & Erkek oyuncu & Sigara kullanan biri \\
\hline İnsan & $\begin{array}{l}\text { Oyuncunun elinin } \\
\text { cebinde olmas1 }\end{array}$ & $\begin{array}{l}\text { Birazdan sigara } \\
\text { içileceği }\end{array}$ \\
\hline İnsan & Erkek oyuncu & Doktor \\
\hline Nesne & Röntgen filmi & $\begin{array}{l}\text { Hastane, hastalık, } \\
\text { tetkik, sonuç }\end{array}$ \\
\hline Nesne & Tomografi cihazı & Hastane \\
\hline
\end{tabular}

Filmin yedinci sahnesinde arabasından inen genç biri "maalesef bırakamam" diyerek sigara içtiğini, bağımlı olduğunu ve sigara içmeyi bırakamayacağını ima etmektedir. Aracından iner inmez yaptığı ilk işin sigara içmek olacağı, elini cebine atmasından anlaşılmaktadır.

Son sahnede ise izleyicinin karşısına bir doktor çıkmaktadır. Doktor "çok geç, ameliyat edemem" diyerek hastasının sağlık durumundaki ciddiyeti anlatmaktadır. Arka planda görünen röntgen filmi kişinin akciğerleri ile ilgili bir hastalık yaşadığına gönderme yapmaktadır. Bağımlının "maalesef bırakamam" repliğine karşın doktor da "maalesef ben de 
ameliyat edemem" diyerek adeta bağımlıya karşılık vermektedir.

Her iki sahne birlikte değerlendirildiğinde sigara içmeye devam edilmesi halinde telafi edilemeyecek sağlık sorunlarıyla karşılaşılabileceğinin mesajı verilmektedir. Sigarayı bırakamayacağını söyleyen bireyler, bunun tamamen kendi tercihleri olduğu, kendi iradesi ile isterlerse bırakabilecekleri, ilerleyen bir hastalı̆̆ın bazen tedavisinin mümkün olmayacağı mesajıyla uyarılmaktadır.

\section{Íkinci Kamu Spotunun Çözümlemesi:}

İkinci film de dokuz sahneden oluşmaktadır. İlk filme benzer şekilde sigaranın zararları, oyuncuların benzer yönlerine göndermeler yapılarak anlatılmıştır. Filmin sahneleri sigara içmeye devam eden ve sigaradan zarar gören hastalar şeklinde birbirini tamamlar nitelikte kurgulanmıştır. Bu nedenle gösterge çözümlemesi yapılırken anlam bakımından birbirileriyle ilişkili sahneler birlikte değerlendirilmiştir.

Resim 10. Sahne-1

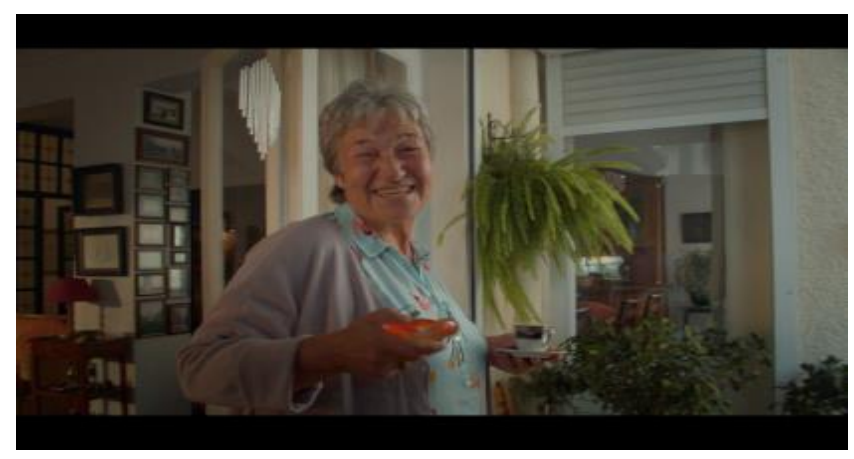

Resim 11. Sahne-2

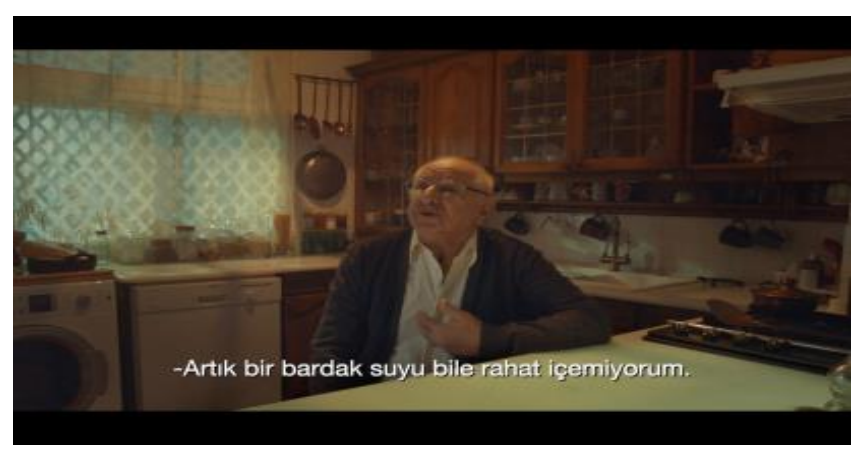

Tablo 5: Sahne-1 ve Sahne-2 Gösterge Çözümlemesi

\begin{tabular}{lll}
\hline Gösterge & Gösteren & Gösterilen \\
\hline İnsan & Kadın oyuncu & $\begin{array}{l}\text { Yaşlı, emekli veya ev } \\
\text { kadını }\end{array}$ \\
\hline Nesne & Kapı, pencere, çiçek & Ev ortamı \\
\hline Nesne & $\begin{array}{l}\text { Resim ve fotoğraf } \\
\text { çerçeveleri }\end{array}$ & $\begin{array}{l}\text { Yaşanmışlık, anı, eski, } \\
\text { tarihi }\end{array}$ \\
\hline Nesne & Kahve fincanı & Keyif \\
\hline Nesne & Kül tabağ1 & Sigara içileceği \\
\hline İnsan & Erkek oyuncu & Yaşlı ve hasta adam \\
\hline Mekan & Arka plandaki eşyalar & Mutfak \\
\hline Alt yazı & Yazı & Konuşmanın tercümesi \\
\hline
\end{tabular}

Film elinde kahvesi ve kül tabağı ile balkona giden yaşlı bir kadının görüntüsü ile başlamaktadır. Kadının elindeki kül tabağı, sigara içtiğinin göstergesi olmuştur. Kadının "bırakmak istiyorum da, kahveyi sigarasız içemiyorum" söylemi onun sigara bağımlısı olduğu, bu bağımlılığı masumlaştırmak için sadece kahve içtiğinde sigara kullandığını ifade ettiği şeklinde yorumlanmaktadır.

İkinci sahnede ise evinin mutfağında sandalyede oturan yaşlı bir adam görülmektedir. Kısık sesi ile "artık bir bardak suyu bile rahat içemiyorum" diyerek boğazında oluşan sağlık problemine gönderme yapmaktadır. Adamın konuşmasının net bir şekilde anlaşılmaması nedeniyle konuşma anında replik altyazı ile izleyiciye gösterilmektedir.

Geçmişte sigara içtiği için hastalanan ve boğazında çok ciddi bir problem yaşayan adam, adeta kadına "sen kahveyi sigarasız içemiyorsun ama ben insanın en temel ihtiyacı olan suyu bile rahatça içemiyorum" demekte ve bağımlıları bu şekilde uyarmaktadır.

Resim 12. Sahne-3

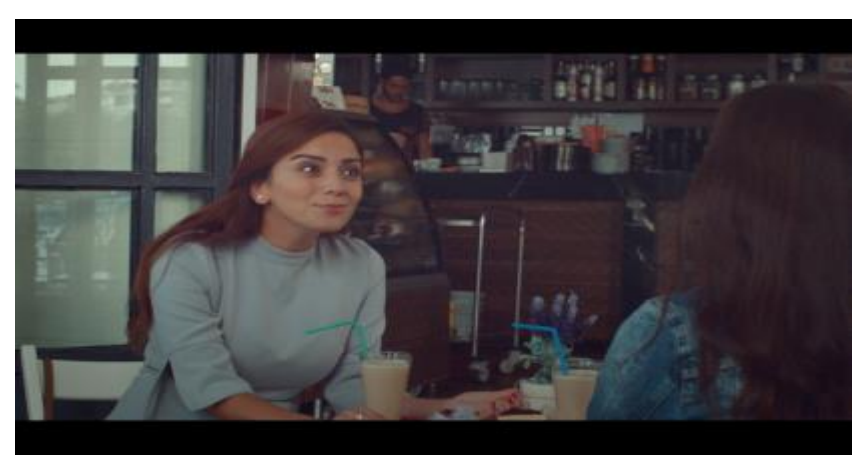

Resim 13. Sahne-4

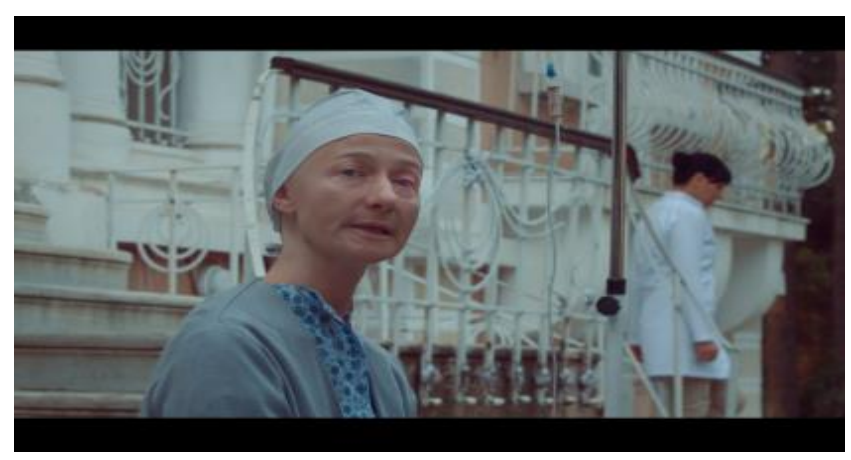

Tablo 6: Sahne-3 ve Sahne-4 Gösterge Çözümlemesi

\begin{tabular}{lll}
\hline Gösterge & Gösteren & Gösterilen \\
\hline İnsan & Kadın oyuncu & $\begin{array}{l}\text { Genç ve sigara içen } \\
\text { kadın }\end{array}$ \\
\hline Mekan & $\begin{array}{l}\text { Arka planda yer alan } \\
\text { nesneler, içecekler }\end{array}$ & Kafeterya \\
\hline İnsan & Kadın oyuncu & Hasta \\
\hline Nesne & Serum & $\begin{array}{l}\text { Tedavinin devem } \\
\text { etmesi }\end{array}$ \\
\hline Mekan & $\begin{array}{l}\text { Arka planda görünen } \\
\text { üniformalı kadın }\end{array}$ & Hastane \\
\hline Mekan & $\begin{array}{l}\text { Demir korkuluklar, } \\
\text { basamaklar }\end{array}$ & Hastanenin bahçesi \\
\hline
\end{tabular}

Üçüncü sahnede kafeterya benzeri bir mekanda oturan genç bir kadının görüntüsü ile başlıyor. "Bir kere bıraktım, üç kilo aldım" diyen kadın, sigara içmeyi daha önce bıraktığı ve kilo aldığı için sigara içmeye devam edeceğinin sinyallerini vermektedir. 
Hemen arkasından gelen dördüncü sahnede başka bir kadının görüntüsü yer almaktadır. Yanında bulunan serum, mekanda görünenler ve arka plandaki üniformalı kadının görüntüsünden bu kadının hastanede tedavi gören bir hasta olduğu anlaşılmaktadır. Geçmişte sigara içmesi nedeniyle sağlık sorunları yaşayan bu kadın "20 kilo verdim" diyerek hastalığı ve tedavisi nedeniyle kilo kaybettiğini söylemektedir. Kadının saçlarının olmaması onun bir kanser hastası olduğuna ișaret etmektedir. Zira kemoterapi ile tedavisi sürdürülen kanser hastalarının ilaçların yan etkisi nedeniyle saçlarının döküldüğü bilinmektedir.

İki sahne birlikte değerlendirildiğinde, sigara kullanmayı bıraktığınızda belki bir kaç kilo alabilirsiniz ama sigara içmeye devam etmeniz halinde çok ciddi hastalıklara yakalanabilirsiniz ve bu nedenle daha fazla zarar görebilirsiniz şeklinde yorumlanabilmektedir.

\section{Resim 14. Sahne-5}

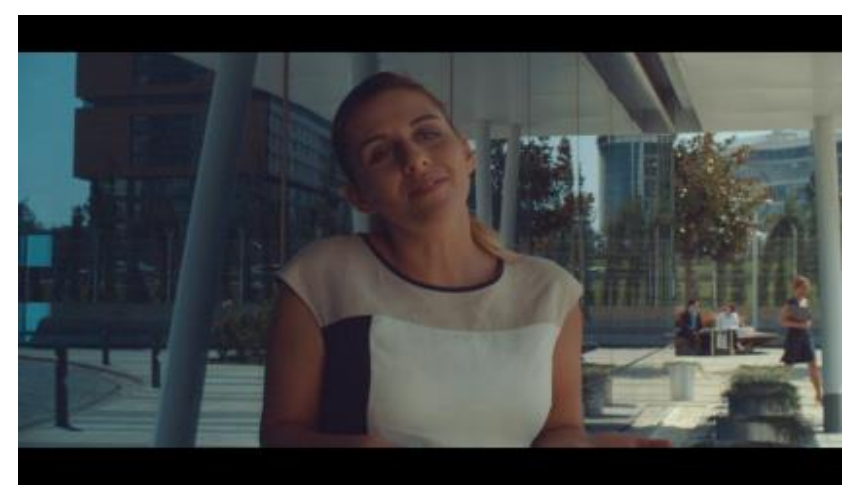

Resim 15. Sahne-6

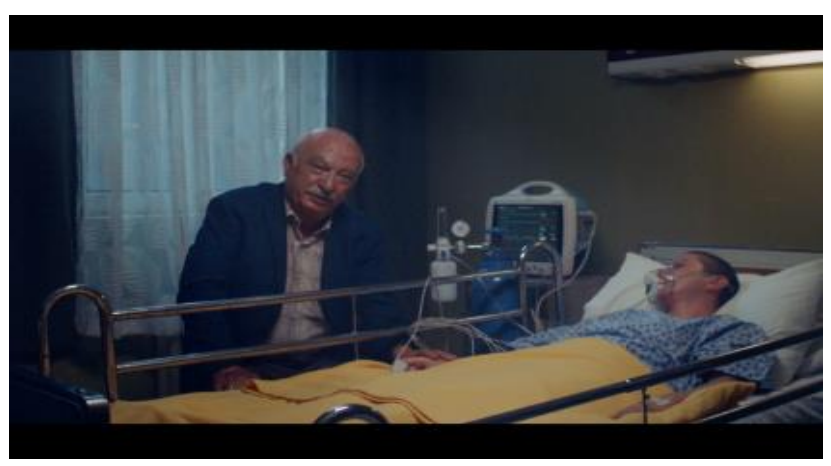

Tablo 7. Sahne-5 ve Sahne-6 Gösterge Çözümlemesi

\begin{tabular}{lll}
\hline Gösterge & Gösteren & Gösterilen \\
\hline İnsan & Kadın oyuncu & Sigara kullanan biri \\
\hline Nesne & $\begin{array}{l}\text { Oyuncunun çantasını } \\
\text { karıştırması }\end{array}$ & $\begin{array}{l}\text { Birazdan sigara } \\
\text { içileceği }\end{array}$ \\
\hline İnsan & $\begin{array}{l}\text { Arka planda oturanlar, cam } \\
\text { duvardan yansıyan görüntü }\end{array}$ & Diş mekan \\
\hline İnsan & Erkek oyuncu & Baba \\
\hline İnsan & Yatakta yatan kişi & Hasta \\
\hline Mekan & $\begin{array}{l}\text { Solunum cihazı, elektronik } \\
\text { aletler }\end{array}$ & Hastane odası \\
\hline
\end{tabular}

Genç bir kadının görüntüsü ile başlayan beşinci sahnede de benzer göstergelerin kullanıldığını söylemek mümkündür. Kadının çantasını karıştırıyor olması ve tam da bu esnada "ya benim içtiğim çok hafif” demesi onun sigara içtiğinin ve birazdan tekrar sigara içeceğinin göstergesi olmuştur.
Bir önceki sahnede içtiği sigaranın hafifliğine değinen kadına karşılık altıncı sahnede görünen yaşlı adam "bu yaşadıklarımız çok ağır" diyerek yaşadıklarının kendisini çok üzdüğünü anlatmaktadır. Mekanda bulunan cihaz ve aletlere bakıldığında oranın bir hastane odası olduğu anlaşılmaktadır. Sigara içtiği için hastalanan ve şu an yatakta yatan bu kişinin yaşlı adamın çocuğu olduğu izlenimi verilmektedir. Hastanın solunum cihazına bağlı olması onun geçmiște sigara içtiğine ve sigara bağımlılığı nedeniyle hastalandığına gönderme yapmaktadır.

İki sahne birlikte değerlendirildiğinde ise sigaranın hafif ya da sert olmasının sigara içmek için bir gerekçe olmadığının, her türlü sigaranın sağlığa zararlı olduğu ve bağımlılığın devamı halinde üzücü durumların yaşanacağı anlatılmaktadır.

Resim 16. Sahne-7

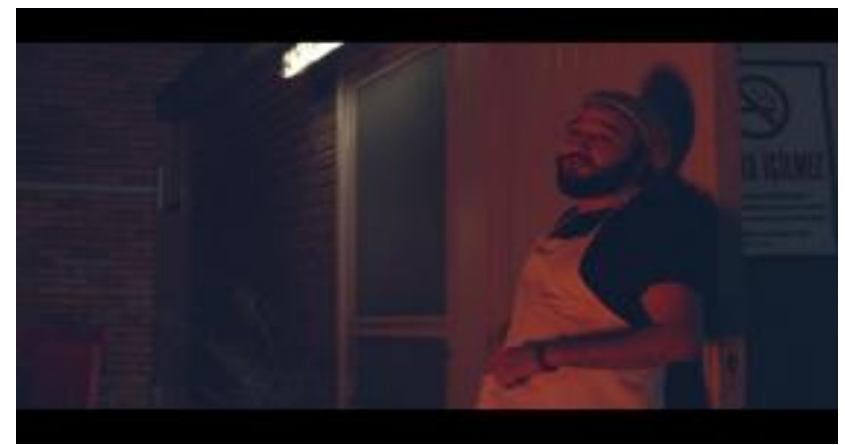

Resim 17. Sahne- 8

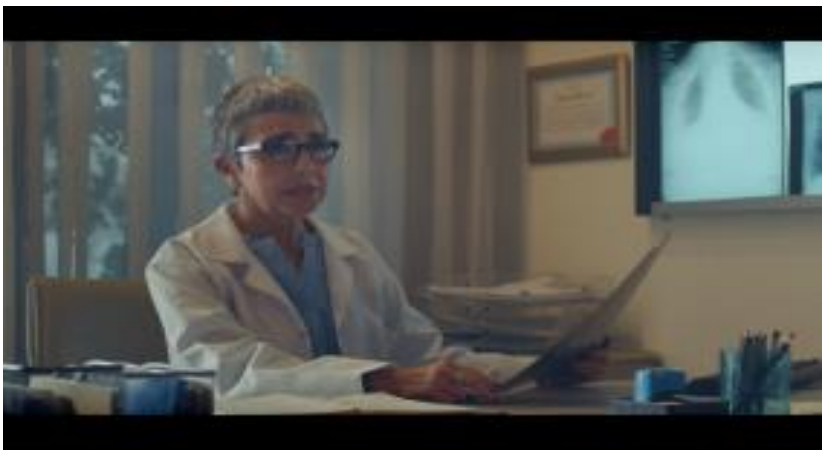

Resim 18. Sahne-9

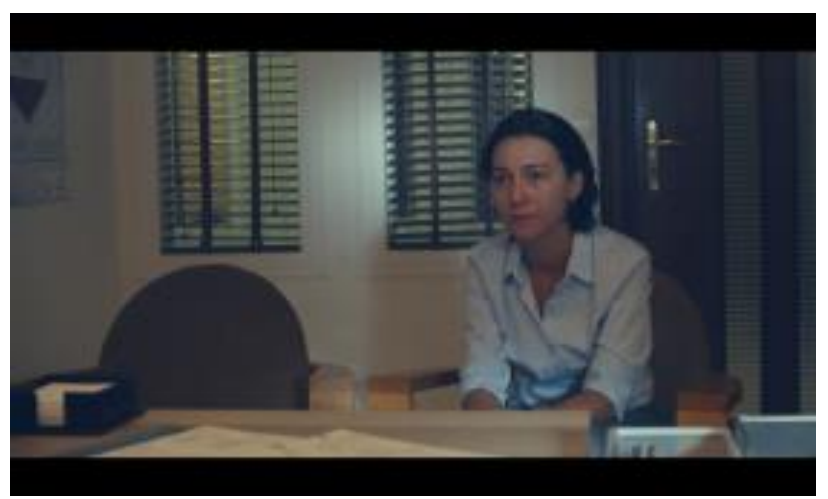


Tablo 8. Sahne-7, Sahne- 8 ve Sahne-9 Gösterge Çözümlemesi

\begin{tabular}{lll}
\hline Gösterge & Gösteren & Gösterilen \\
\hline İnsan & Erkek oyuncu & Sigara kullanan biri \\
\hline İnsan & $\begin{array}{l}\text { Oyuncunun elini cebine } \\
\text { atması }\end{array}$ & $\begin{array}{l}\text { Birazdan sigara } \\
\text { içileceği }\end{array}$ \\
\hline Nesne & Önlük, bone & Mutfak personeli \\
\hline Yazı & Afiş & Sigara yasağ1 \\
\hline İnsan & Kadın oyuncu & Doktor \\
\hline Mekan & $\begin{array}{l}\text { Pencere, perde, çerçeveli } \\
\text { diploma, film }\end{array}$ & Doktor odası \\
\hline Nesne & Röntgen filmi & $\begin{array}{l}\text { Akciğer ile ilgili bir } \\
\text { hastalık }\end{array}$ \\
\hline İnsan & Kadın oyuncu & Hasta \\
\hline
\end{tabular}

Yedinci sahne yine bir iş yeri çalışanının sigara içmek için işine ara verdiği bir görüntü ile başlıyor. Üzerindeki önlük ve başındaki boneden anlaşıldığı üzere bu kişinin yemek yenilen bir mekanın mutfağında çalışan bir aşçı olduğu izlenimi oluşmaktadır. "Abi bir gün bırakırım ya, daha çok vakit var" diyen oyuncu, elini cebine doğru götürerek birazdan sigara içeceğini göstermektedir. Arka planda duvarda asılı olan sigara yasağına yönelik afiş dikkat çeken bir başka gösterge olmuştur. Sigara içilmesinin yasak olduğu bir ortamda çalışmasına ve bu konuda uyarılmasına rağmen kişinin sigara içmeye devam etmesi, günlük hayatta birçok kişinin karşılaştığı bir durumdur.

Sekizinci sahne bir önceki sahneye gönderme yaparak, görüntüye gelen doktor elindeki filme bakarak "maalesef çok geç" diyerek zaman kavramına vurgu yapmaktadır. Doktorun arkasında görünen ve sigaranın insan üzerinde zarar verdiği ilk organ olarak bilinen akciğer filmi de sigara içen bir hastaya gönderme yapmaktadır.

Dokuzuncu sahne ise aynı mekanda geçmektedir. Doktorun repliğinden hemen sonra ekrana gelen kadının korkulu ve endişeli gözlerle doktora bakmasını hasta olanın o olduğu ve daha önce sigarayı bırakmadığı için pişman olduğu şeklinde yorumlamak mümkündür.

Filmin son sahneleri birlikte değerlendirildiğinde, sigarayı bırakmanın bir yaşı ya da zamanının olmadığına vurgu yapılarak, sigarayı bırakmak için geç kalınmaması gerektiği ve geçen her anın, sigaradan daha fazla zarar görüleceği mesajı verildiği sonucuna varmak mümkündür.

\section{Üçüncü Kamu Spotunun Çözümlemesi:}

Üçüncü ve son film de sekiz sahneden oluşmaktadır. İlk iki filmden farklı olarak sigara içmeye devam edenlerle sigarayı bırakmış kişilerin gösterildiği sahnelerden oluşmaktadır. Yine filmdeki sahneler anlam bakımından birbirileriyle ilişkilendirilmiştir. $\mathrm{Bu}$ nedenle gösterge çözümlemesi yapılırken birbirileriyle ilişkili sahneler birlikte değerlendirilmiştir.

Resim 19. Sahne-1

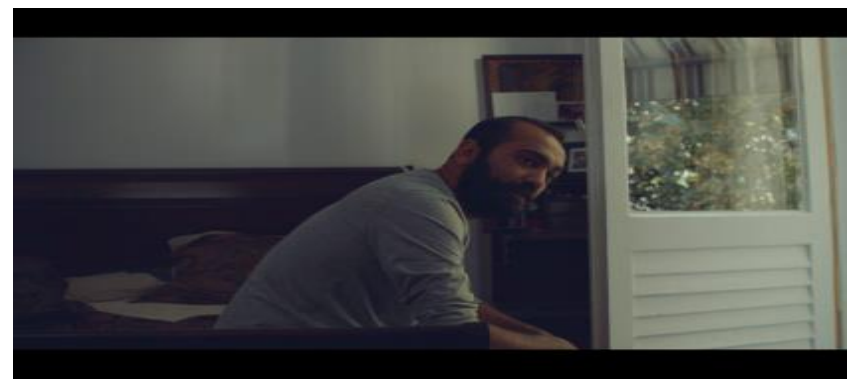

Resim 20. Sahne-2

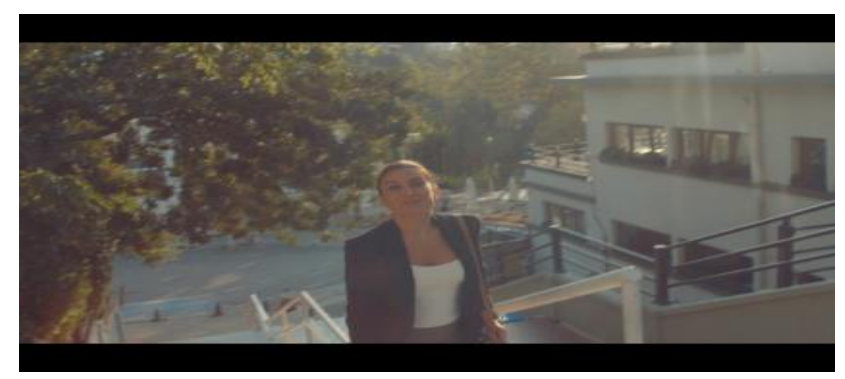

Tablo 9. Sahne-1 ve Sahne-2 Gösterge Çözümlemesi

\begin{tabular}{lll}
\hline \multicolumn{2}{l}{ Gösterge Gösteren } & Gösterilen \\
\hline İnsan & Erkek oyuncu & Sigara kullanan biri \\
\hline Nesne & Kül tabağı & Birazdan sigara içileceği \\
\hline Mekan & Yatak & İç mekan, yatak odası \\
\hline İnsan & Kadın oyuncu & Çalışan kadın \\
\hline Mekan & Basamaklar, ağaçlar, binalar & Dış mekan \\
\hline Doğa & Güneş 1şı̆̆ & Sabah saatleri \\
\hline
\end{tabular}

Üçüncü ve son filmin ilk sahnesi yatağında oturmuş ve söylediği replikten anlaşılan yeni uyanmış ve sigara kullanan biriyle başlamaktadır. "Bir tane sigara içmeden imkanı yok ayılamıyorum" diyen oyuncu sigaraya olan bağımlılığını aktarmaktadır. Yatağında oturması, hareketsizliği ve durağan bir görüntünün olması sigaranın ona verdiği zararların göstergesi olmuştur. Buna karşın ikinci sahnede merdivenleri koşar adımlarla çıkan kadın "bıraktığımdan beri çok daha zinde kalkıyorum" diyerek sigarayı bırakmanın kendisine vermiş olduğu enerjiyi ve mutluluğu yansıtmaktadır. Sahnenin diş mekanda çekilmiş olması dinamik bir görüntünün oluşmasına neden olduğu gibi güneş ışığının geliş açısına bakıldığında da çekimin sabah saatlerinde yapıldı̆̆ı anlaşılmaktadır.

İki sahne birlikte değerlendirildiğinde, sigara içen biriyle sigara içmeyen birinin sabah uyandığında farklı psikolojik ve fiziksel durumlarda olacağına, sigarayı bırakan birinin sigara içmeye dem eden birine göre daha zinde, enerjik ve mutlu bir şekilde güne başlayacağı gösterilmiştir.

Resim 21. Sahne-3

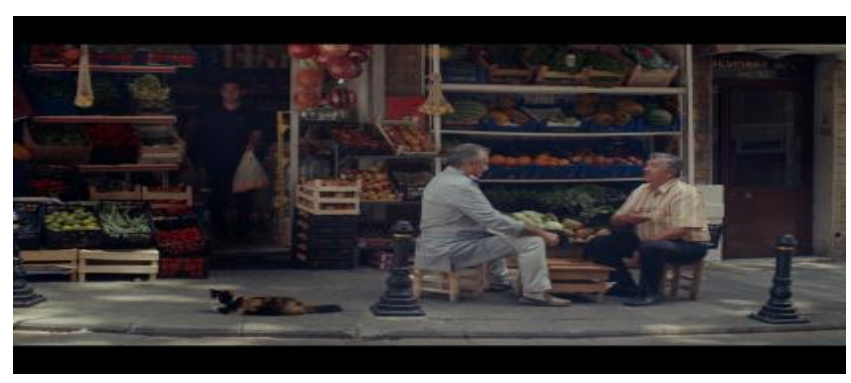

Resim 22. Sahne-4

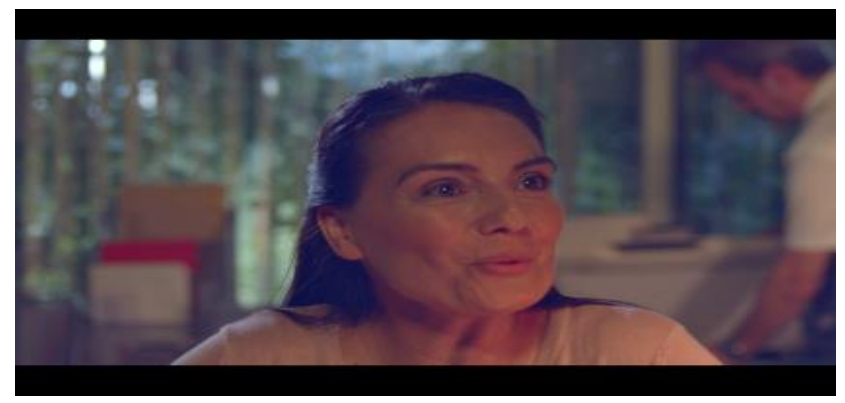


Tablo 10. Sahne-3 ve Sahne-4 Gösterge Çözümlemesi

\begin{tabular}{lll}
\hline Gösterge Gösteren & Gösterilen \\
\hline İnsan & Erkek oyuncular & Esnaflar \\
\hline İnsan & Genç oyuncu & Müşteri veya çırak \\
\hline Mekan & $\begin{array}{l}\text { Sebze-meyve reyonu, } \\
\text { plastik toplar }\end{array}$ & Market \\
\hline Hayvan & Kedi & Huzurlu ve sakin bir ortam \\
\hline Oyun & Tavla & $\begin{array}{l}\text { Geleneksellik, mahalle } \\
\text { esnafi }\end{array}$ \\
\hline İnsan & Kadın oyuncu & $\begin{array}{l}\text { Sigarayı bırakmış mutlu } \\
\text { kadın }\end{array}$ \\
\hline Mekan & $\begin{array}{l}\text { Erkek oyuncu, fotokopi } \\
\text { makinası }\end{array}$ & $\begin{array}{l}\text { Kırtasiye veya benzeri bir } \\
\text { işletme }\end{array}$ \\
\hline
\end{tabular}

Filmin üçüncü sahnesinde bir marketin önünde oturup tavla oynayan iki esnafın görüntülerine yer verilmiştir. Tok bir sesle "Benim de bir masrafim bu var" diyerek eli ile cebini işaret etmektedir. İşaret ettiği şeyin sigara olduğu anlaşılmaktadır. Oyuncunun ses tonundaki tokluk, sigara içtiğine gönderme yapmaktadır. Sigara sadece insan sağlığına zarar vermekle kalmamakta aynı zamanda maddi zararların oluşmasına da neden olmaktadır. Üçüncü sahnedeki esnaf karakterini canlandıran oyuncunun verdiği mesajdan, sigaranın sağlığının yanı sıra ekonomik durumuna da etki ettiğinin farkında olduğu anlaşılmaktadır. Zira burada eli ile işaret ettiği 'cep' aynı zamanda 'cebine zarar vermek' deyimi ile ilişkilendirilebilir. $\mathrm{Bu}$ repliği, bir suçluluk psikolojisi olarak değerlendirmek de mümkündür. Arka plan olarak sebze ve meyve reyonlarının kullanılmasını ise ironik bir yaklaşım olarak değerlendirilebilir.

Dördüncü sahnede ise yakın plan çekim ile ekrana bir kadın oyuncu yansımaktadır. Kadının yüzündeki mutlu, canlı ve enerjik durumun yansıtılması bakımından yakın plan çekim yapıldığı düşünülmektedir. Önceki sahnenin aksine daha dinamik ve hareketli görüntülere yer verilmiştir. Arka plandaki nesne ve mekana bakıldığında kırtasiye veya benzeri bir iş yeri ortamı olduğu anlaşılmaktadır. "Benim de günde 10 lira bağışla okuttuğum bir öğrencim var” diyen kadın, adeta önceki sahnede bulunan esnafa cevap vermektedir. Bunu söylerken de yüzüne mutlu ve gururlu bir ifade yansımaktadır.

İki sahnenin birlikte verdiği mesaj, sigara içerek sağlığınıza ve ekonominize zarar vereceğinize, sigarayı birakarak hem sağlığınızı koruyun, hem de sigaraya verdiğiniz parayı faydalı işlerde kullanın şeklinde değerlendirilebilir.

Resim 23. Sahne-5

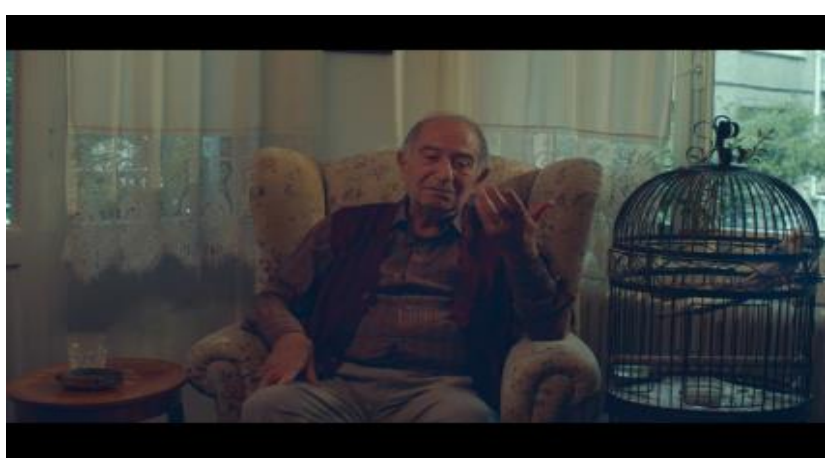

Resim 24. Sahne-6

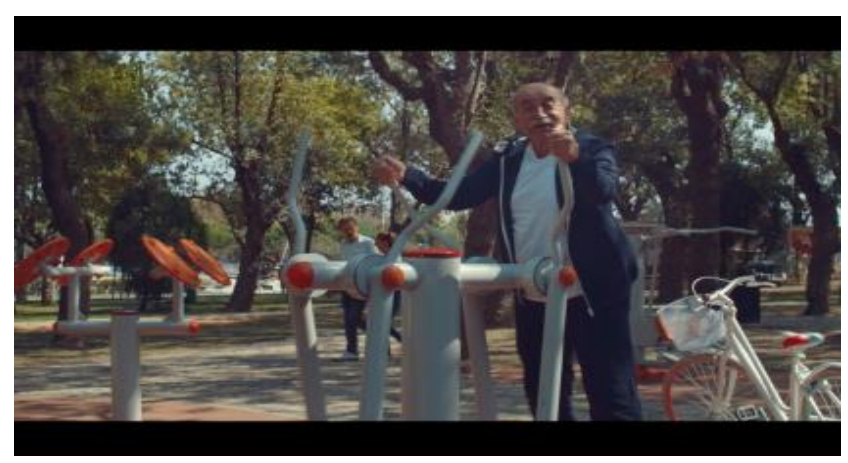

Tablo 11. Sahne-5 ve Sahne-6 Gösterge Çözümlemesi

\begin{tabular}{lll}
\hline Gösterge & Gösteren & Gösterilen \\
\hline İnsan & Erkek oyuncu & $\begin{array}{l}\text { Sigara kullanan yaşlı ve } \\
\text { yorgun adam }\end{array}$ \\
\hline Nesne & Koltuk & Geleneksellik, klasiklik \\
\hline Hayvan & $\begin{array}{l}\text { Kafesiyle birlikte } \\
\text { duran papağan }\end{array}$ & $\begin{array}{l}\text { Geleneksellik, hayvan } \\
\text { severlik }\end{array}$ \\
\hline Nesne & Kül tabağı & Sigara içildiği \\
\hline Nesne & Su bardağı & $\begin{array}{l}\text { İlaç kullanıldığı, ani } \\
\text { rahatsızlıkların } \\
\text { olabileceği }\end{array}$ \\
\hline İnsan & Erkek oyuncu & $\begin{array}{l}\text { Sigarayı bırakmış yaşlı } \\
\text { ama sağliklı ve mutlu } \\
\text { adam }\end{array}$ \\
\hline Nesne & Spor aletleri & Spor yapılabilen park \\
\hline Nesne & Bisiklet & $\begin{array}{l}\text { Motorlu araç } \\
\text { kullanılmadı̆̆ }, \text { spor }\end{array}$ \\
\hline Doğa & Ağaçlar & Park, ormanlık alan \\
\hline
\end{tabular}

Filmin beşinci sahnesinde sigara içtiği anlaşılan yaşlı ve yorgun bir adam yer almaktadır. Evde koltuğuna oturmuş, yanında evcil hayvanı, sehpası ve sehpa üzerinde bulunan kül tabağı ile görünen bu adam, "Yani bu yaştan sonra sigarayı bıraksam ne fark eder" demektedir. Bu adamın, sigarayı bırakmayı düşünmediğini ve yaşı nedeni ile yaşama dair umutlarını tükettiğini söylemek mümkündür. $\mathrm{Bu}$ düşünce yapısı içerisinde evinden çıkmayan ve sağlıklı bir yaşam sürdürmeyen bir portre çizmektedir. Sehpa üzerinde bulunan su bardağı, adamın sağlık sorunları yaşadığına, ilaç kullandığına ve ani rahatsılılılar geçirebileceğine işaret etmektedir.

Sonra gelen altıncı sahnede ise tam tersi bir durum gösterilmektedir. Bir önceki sahnenin durağanlığına karşın bu sahne hareketli ve enerjik bir yapıya sahiptir. Açık havada ormanlık bir alanda spor aletiyle spor yapan bir adam "Gençleştim resmen, bu kadar mı fark eder" diyerek hareketli ve dinamik bir görüntü sergilemektedir. Kullanılan replikten anlaşıldığı gibi bu kişinin daha önce sigara içtiği yaşına rağmen sigarayı bıraktıktan sonra kendini genç hissettiği anlaşılmaktadır. Arka planda görünen bisiklet, adamın buraya bisiklet sürerek geldiği ve sağlıklı olduğu izlenimini yaratmaktadır.

İki sahnenin birlikte verdiği mesajı, sigaranın fiziksel zararlarının yanında psikolojik zararlar da verdiği, sigarayı bırakmanın yaş ve zamanla ilgili bir durum olmadığı, zararın neresinden dönülse kar sayılacağı, sigaranın bırakılması halinde fiziksel ve psikolojik etkilerinin olumlu bir şekilde yansıyacağı şeklinde yorumlamak mümkündür. 
Resim 25. Sahne-7

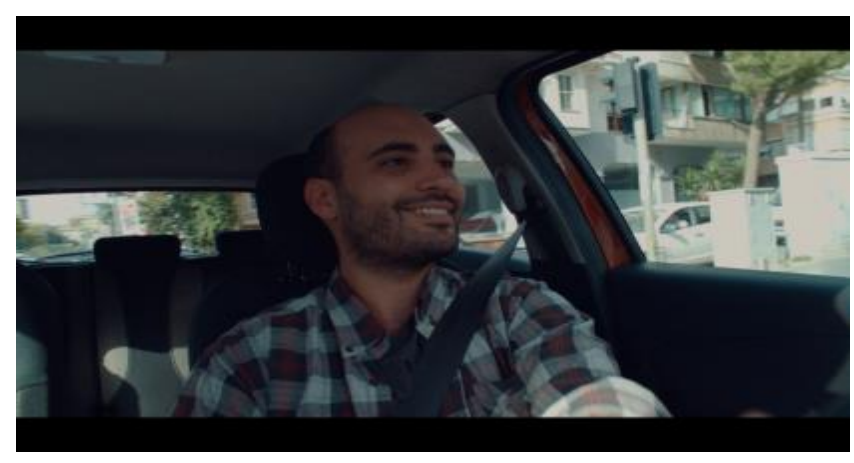

Resim 26. Sahne-8

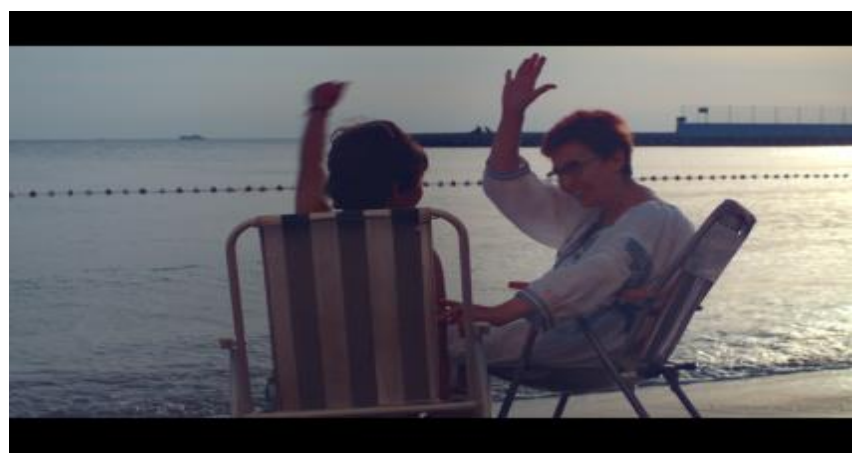

Tablo 12. Sahne-7 ve Sahne-8 Gösterge Çözümlemesi

\begin{tabular}{lll}
\hline Gösterge & Gösteren & Gösterilen \\
\hline İnsan & Erkek oyuncu & Sigara kullanan biri \\
\hline Nesne & Emniyet kemeri & Bilinçli birey \\
\hline İnsan & Kadın oyuncu & $\begin{array}{l}\text { Sigarayı bırakmış } \\
\text { sağlıklı ve mutlu kadın }\end{array}$ \\
\hline İnsan & Çocuk oyuncu & Gelecek nesil \\
\hline Doğa & Deniz & Açık ve temiz hava \\
\hline
\end{tabular}

Filmin yedinci sahnesinde araba kullanan erkek oyuncunun "Bir kere bıraktım sonra tekrar başladım" repliği ile başlamaktadır. Araç kullanırken emniyet kemeri takma bilincine sahip birinin sigara içiyor olması, kişinin kendi içinde yaşadığ ironiye gönderme yapmaktadır.

Filmin son sahnesinde gelen kadın ise bir önceki sahnede sigarayı bir kez bırakmayı deneyip bırakamayan adama cevap vermektedir. "Tekrar tekrar denedim, en sonunda başardım. Tam 10 yıldır ağzıma sürmüyorum” diyerek sigarayı bıraktığını söylemektedir. Deniz kenarında mutlu ve huzurlu bir hayat süren bu kadın sigarayı bıraktığı için ne kadar mutlu olduğunu yanında oturan çocuk ile yaptığı 'çak' hareketiyle göstermektedir. $\mathrm{Bu}$ hareket, aynı zamanda sigaraya karşı kazanılmış bir zaferin göstergesi olmuştur.

Her iki sahne birlikte değerlendirildiğinde ise sigarayı bırakmak isteyenlerin kararlı bir şekilde sigarayı bırakana kadar mücadele etmeleri ve pes etmemeleri gerektiği mesajının verildiğini söylemek mümkündür.

\section{Sonuç ve Öneriler}

Sigaranın kullanım yaşının hızla düştüğü günümüzde artık ilkokul önlerinde bile sigara içen çocuklara rastlanılmaktadır (Sigara, 2018). Bu noktada T.C. Sağlık Bakanlığı'nın yanı sıra toplum yararına çalışan çeşitli kurum, kuruluş ve sivil toplum örgütlerinin yaptıkları sosyal sorumluluk projeleri, görsel iletişim araçları vasıtasıyla toplumu bilinçlendirme çalışmaları devam etmektedir. Özellikle son 10 yıl içerisinde
T.C. Sağlık Bakanlığı Sağlığın Geliştirilmesi Müdürlüğü tarafından bu konuda çalışmalar yapıldığı görülmektedir. Sosyal afiş tasarımları, billboardlar, açık hava reklamları ve kamu spotları bu çalışmaların önde gelenleridir. Televizyon izleme oranlarının oldukça yüksek olduğu Türkiye'de kamu spotlarının insanlar üzerinde önemli ölçüde etkili olduğu söylenebilir.

Araştırmanın örnekleminde sigarayı bıraktırmaya ve sigara konusunda toplumu bilinçlendirmeye yönelik hazırlanmış olan kamu spotları yer almıştır. Sigaranın getirdiği sağlık sorunları ve ekonomik zararlarının giderek artması, ölümcül hastalıklara neden olması ve insanların yaşam kalitesini düşürmesi araştırmanın temelini oluşturan bu filmlerin hazırlanması ihtiyacını doğurmuştur. İnsan sağlığını ve dolayısı ile toplumu tehdit eden tütün ve tütün ürünleri bağımlılı̆̆ı ile ilgili yapılan bu filmler, toplumu uyarması, bilinçlendirmesi ve aynı zamanda eğitmesi bakımından son derece önemlidir.

Üç filmde de, hedef kitleyi sigara ve zararlarına karşı uyarıcı, aynı zamanda eğitici mesajların olduğu açıktır. Üç fillmin hikayesi de benzer şekilde kurgulanmıştır. Kullanılan renkler, kompozisyon ve sinematografik öğeler birbirine benzer şekildedir. Sinematografik açıdan kullanılan tekniklerin yanı sira oyuncu performanslarının da tatmin edici seviyede olduğunu söylemek mümkündür. Genel olarak sigaraya ve zararlarına karşı farkındalık yaratma noktasında kullanılan görsel göstergelerin düz anlamlarının yanı sıra yan anlamlarıyla da mesajı verebildiğini söylemek mümkündür. Üç filmde de sigaranın kendisi gösterilmeden tamamen göstergeler üzerinden sigaraya işaret edildiği gözlenmiştir. Filmdeki karakterlerin kimi zaman cebini göstererek, kimi zaman çantasını karıştırarak, kimi zaman da kadraja giren kül tabağı gibi herhangi nesne ile sigaraya göndermeler yapılmıştır. Filmlerin bitiş kısımlarının aynı olması da projenin bütünselliğine katkı sağlamıştır. "Sigarayı Bırak Hayatı Bırakma" sloganı üç filmde de kullanılarak hem hedef kitleye net mesaj verilmiş, hem de filmde sunulan mesajların toparlayıcısı olarak sunulmuştur.

İlk iki filmde sigara içmeye devam edenler ve sigara içtikleri için hastalanan kişiler gösterilmektedir. Mesajlar birbirini tamamlar nitelikteki diyaloglardan oluşmaktadır. İlk iki film daha çok insanları uyarmayı hedefleyen niteliktedir. İzleyicilere "sigara içmeye devam ederseniz siz de hastalanabilir ve telafisi mümkün olmayan durumlarla karşılaşabilirsiniz" denilmekte ve çok geç olmadan sigarayı bırakmaları gerektiği mesajı verilmektedir. Her iki filmin sonunda da görünen doktor figürü ve verilen mesajlar, sigaranın verdiği zararlar nedeniyle tedaviye geç kalındığı şeklindedir.

Son filmde ise ilk iki filmde hedeflenen insanları uyarma noktasında başarılı sonuçlar alındığına gönderme yapılarak sigara içmeye devam edenlerle sigarayı bırakmayı başaranların diyalogları gösterilmektedir. Bir yandan toplumda sigara içmenin devam ettiği, diğer taraftan da sigarayı bırakanların olduğu ve bu her iki kesimin de ne durumda oldukları ile ilgili topluma negatif ve pozitif mesajlar aktarıldığı söylenebilir. Sigara içenlerin bulunduğu sahnelerde hareketsiz ve durağan görüntülerin kullanılmasına karşın sigarayı bırakmış olan kişilerin bulunduğu sahnelerin daha hareketli ve dinamik olduğu gözlenmektedir. Yine ilk iki filmin sonunda yer alan doktorların uyarı mesajları yerine bu kez sigarayı bırakmayı 
başarmış birinin görüntüsüne ve mesajına yer verilerek sigara içen izleyiciyi özendiren görüntülerin kullanılması tercih edilmiştir. İlk iki filmde izleyiciyi uyaran mesajlar verilirken, son filmde de "siz de sigarayı bırakmayı başarabilirsiniz" mesajı verilmektedir. Bu durum, kamu spotlarının kısmen de olsa amacına ulaştığını göstermektedir.

Tütün ve tütün ürünlerine bağımlılıkla mücadele kapsamında bu araştırmanın örnekleminde olan kamu spotlarının, yeni senaryolarla devam ettirilmesi gerektiği, etkili bir görsel iletişim aracı olan kamu spotu çalışmalarının, insanları sağlık konusunda bilgilendirmesi ve bilinçlendirmesi bakımından bağımlılıkla mücadeleye katkı sağlayacağı, insanların tutum ve davranışlarını değiştirmelerinde etkili olabileceği düşünülmektedir.

\section{Kaynakça}

Ambrose, G., \& Harris, P. (2012). Grafik Tasarımın Temelleri. İstanbul: Literatür Yayınları.

Avcı, K., \& Avşar, Z. (2014). Sağlık İletişimi ve Yeni Medya. İletişim Kuram ve Araştırma Dergisi, 39 (Güz), 181-190.

Aytekin, H. (2016). Görsel-İşitsel Medyada Sağl1k Güvenlik Halleri: Tartışılması Gereken Bir Alan Olarak Kamu Spotu. Selçuk İletişim, 9 (3), 249-275.

Barthes, R. (1993). Göstergebilimsel Serüven. İstanbul: Yap1 Kredi Yayınları.

Becerikli, Yıldırım, S. (2012). Sağlık İletişimi Çalışmalarında Alımlama Analizinin Kullanımı: Odak Grup Çalışması Yoluyla Kamu Kampanyaları Ve Reklam Metinlerine İlişkin Çapraz Bir Okuma Pratiği. İstanbul Üniversitesi İletişim Fakültesi Dergisi, 2(43), 163-177

Berger, A. A. (1982). Kitle Iletişiminde Çözümleme Yöntemleri. (Çev: Murat Barkan vd.). Eskişehir: Anadolu Üniversitesi Basımevi.

Bıcal, A., \& Yılmaz, A. (2017). Ayrıntılandırma Olasılığı Modeli Çercevesinde Kamu Spotlarının İncelenmesi: Portakal ve Fındık Tüketimine Yönelik Örnekler. INIF E Dergi, 2-2, 38-54.

Brown, J. D., \& Witherspoon, E. M. (2002). The mass media and American adolescents' health. Journal of adolescent health, 31(6), 153-170.

Chauhan, A., \& Sharma, R. (2017). Impact of Anti Smoking Campaigns on Youth. Procedia computer science, 122, 941-948.

Çınarlı, İ. (2008). Sağllk İletişimi ve Medya. Ankara: Nobel Yayınevei.

Çınarlı, İ. (2016). 'Stratejik' Sağlık İletişiminin Sağlığın Tıbbileştirilmesindeki Rolü. Iletisim Kuram ve Arastirma Dergisi, 2016(43), 203-216.

Çobaner, A. A. (2013). Sağlık İletişiminde Korku Öğesinin Kullanımı: Sigara Paketlerinde Kullanılan Sigara Karşıtı Görsellerin Göstergebilimsel Analizi. İletişim Kuram ve Araştırma Dergisi, 37 / Güz, 211-235.
Dietz, N. A., Sly, D. F., Lee, D. J., Arheart, K. L., \& McClure, L. A. (2013). Correlates of smoking among young adults: the role of lifestyle, attitudes/beliefs, demographics, and exposure to anti-tobacco media messaging. Drug and alcohol dependence, 130(1-3), 115-121.

Duffy, M. E., \& Thorson, E. (2009). Emerging trends in the new media landscape. In: Health communication in the new media landscape, 93-116, Jerry Parker and Esther Thorson (Ed.). New York: Springer Publishing Company.

Erkman-Akerson, F. (2005), Göstregebilime Giriş. İstanbul: Multilingual.

McCool, J. P., Cameron, L. D., \& Petrie, K. J. (2001). Adolescent perceptions of smoking imagery in film. Social science \& medicine, 52(10), 1577-1587.

Okay, A. (2014). Sağlık İletişimi. İstanbul: Der Kitapevi.

Park, E., Kulbok, P. A., Keim-Malpass, J., Drake, E., \& Kennedy, M. J. (2017). Adolescent smoking prevention: Feasibility and effect of participatory video production. Journal of pediatric nursing, 36, 197-204.

Parsa, S. (2008). Film Çözümlemeleri. İstanbul: Multilingual.

Peirce, C. (1982). Writings of Charles S. Pierce. Cilt: 1.

Primack, B. A., Gold, M. A., Land, S. R., \& Fine, M. J. (2006). Association of cigarette smoking and media literacy about smoking among adolescents. Journal of Adolescent Health, 39(4), 465-472.

RTÜK (2012). Kamu Spotları Yönergesi. (Erişim Tarihi: 06.06.2018), https://www.rtuk.gov.tr/kamuspotlari/5029/3985/kamu-spotlari-yonergesi.html

Schiavo, R. (2007). Health Communication: From Theory to Practice. San Fransisco: Jossey-Bass.

Sigara (2018). Sigara. (Erişim Tarihi: 22.01.2018), http://www.sigara.web.tr

Şeker, M., \& Tiryaki, S. (2013). Sigara ile İlgili Kamu Spotlarında Moral Panik Etkisi. Selçuk Üniversitesi Türkiyat Araştırmaları Dergisi, 1(33), 223-241.

Tabak, R. S. (2006). Sağllk İletişimi. İstanbul: Literatür Yayınları.

Tengilimoğlu, D. (2001). Să̆lık Kuruluşlarında Halkla Illişkiler. Ankara: Gazi Kitapevi. 